\title{
Politologia
}

\section{Party funding regulation in Poland (1990-2015): an appraisal}

\section{Fernando Casal Bértoa}

University of Nottingham

\section{Abstract}

In the second half of 2015 Poland held a referendum in which voters were asked to give their opinion on the way party funding was regulated. Of those 7.8 percent of voters who turned out at the polls, only 17.4 percent voted in favour of the system of public funding in force at the time. Taking into consideration such a "negative" social opinion regarding the Polish regime of party funding, this article examines how political party funding (both public and private) is regulated in Poland, how it has changed over time, and how it could be developed. The main conclusion is that even if the current regime is better than the one existing before 2001, there is still much room for improvement.

\section{Keywords}

party funding, political parties, Poland, 1990-2015

\section{Introduction}

n $6^{\text {th }}$ September 2015 Polish voters went to the polls to participate in a referendum in which, among other things, they were asked to take a position concerning the way political parties were funded (Hartliński, 2015). More than four fifths (i.e. 82.6 percent) of those who participated opposed the then-current method of financing political parties from the national budget. The referendum, which had been called by (now former) President Bronisław Komorowski in the aftermath of the first round of the May presidential elections ${ }^{1}$, turned out to be

1 With this move Komorowski expected to win over, in the second round of voting in the presidential election contest, some of the supporters of Paweł Kukiz, a rock-star who opposed - among other things - State financial aid to political parties. Kukiz had obtained $20.8 \%$ of the votes during the first round of voting. 
not legally binding as it failed to reach the required 50 percent voter turnout threshold.

Taking into consideration that only 17.4 percent of those 7.8 percent who turned out at the polls supported the current system of public party funding, it seems the right time to examine how the issue of funding political parties is regulated in Poland, how it has changed over time, and how it could be improved. In order to do that I build on the data collected for the Party Law in Modern Europe project carried out under the auspices of the University of Leiden ${ }^{2}$, as well as in various interviews (available from the author upon request) with politicians, academics, lawyers, journalists and finance experts, conducted in the course of my fieldwork in Poland during the summer of $2013^{3}$.

\section{The four phases of party funding regulation in Poland}

In clear contrast to most Western as well as post-communist democracies (e.g. Croatia, Lithuania, Serbia, Romania), Poland does not have a proper party funding law (Casal Bértoa and Biezen, 2017). Moreover, and with the exception of the 2001 reform, the legislative changes to party funding regulations have always taken the form of small modifications (e.g. 1998 or 2000), as politicians are in general afraid that the proposed reforms may turn against their interests at the end. Thus changes, whether banal or really necessary, in the system of party funding are difficult to undertake.

In terms of the regulation of party funding in Poland, it is possible to distinguish four very different periods:

2 Available at http://www.partylaw.leidenuniv.nl

3 For more information, see the website above. I would like to gratefully acknowledge the support of the European Research Council (ERC starting grant 205660) in the preparation of this article. 


\section{1. $1990-1993$}

The 1990 Party Law (PL) only contained one article (out of 7) regulating the sources of funding (e.g. membership fees, gifts, inheritance, bequests, property income and business income, as well as public donations), but without any dispositions on transparency (except for a very general and vacuous obligation in Art. 6.8), financial control, or sanctions. Parties, which were guaranteed free access to both public radio and television (Art. 7), were even allowed to undertake certain business activities (i.e. own co-operatives or be share-holders in companies). Moreover, the income obtained from such activities was not taxed, provided that 'was used for activities envisaged by its [a party's] constitution' (Art. 6.7).

All in all, during this first period the regulation was very formal and did not really resolve problems in terms of party finance.

\section{1993-1997}

In contrast to the rest of the Visegrad countries (Casal Bértoa and Biezen, 2017), state aid for the financing of parties' ordinary activities was not introduced in Poland until 1993. Even then it was limited to only parliamentary parties, that is, those which obtained at least five percent (eight percent for coalitions) of the votes in a parliamentary election.

Although at this time it was possible to already recognize a trend towards the public funding of Polish politics that would dominate party regulation in Poland after 2001 (see below), private funding was also allowed in a very extensive manner. Indeed, it was not only possible to be involved in certain economic activities (see above), but also to be the beneficiary of public donations, or even to undertake 'public collections' at the time of elections, not just for electoral committees (ECs) but also for parties. One of the most famous forms of 'public collections' was the selling of so-called 'bricks', even anonymously. The only condition was that the sales proceeds had to be deposited

4 Similar to commemorative titles or cards. The idea, justified in the public mind, was that it was easier to 'sell' these 'bricks' than simply collect money with a bag or box like in the church. 
in one bank account in order to determine whether they were under the acceptable limit ${ }^{5}$. Still, because the money was initially collected in a simple bag or box by the parties' and ECs' volunteers, this clearly allowed for contributions coming from private interests.

The fact that such a wide variety of sources of funding were allowed needs to be seen from the perspective of the great difficulties, and not only financial, most parties were experiencing at this stage 6 . It should be noted that from June 1989 until October 1991, when the first free and fair legislative elections took place, a trade union (i.e. Solidarity) rather than a party exerted influence as the real engine of political life. It was a time when the very word 'party' created distrust, if not fear'.

\section{1997-2001}

With the approval of the new Constitution in 1997 and a new PL immediately afterwards, the regulation of parties' finances became a bit more serious, at least in terms of pages (containing more than 20 articles), although less so in terms of content. Thus, with the exception of the principle of transparency, which had been included in both the Constitution and original formulation of the 1997 PL regarding funding, party oversight was not very strict. Although the new PL contained a system of public subsidies, also guaranteed to extra-parliamentary parties (those which obtained at least three percent of the votes in a parliamentary election), a lot of private sources of funding were still permitted; namely from businesses, anonymous donations, contributions by companies, etc.

5 For the presidential elections, the amount of these collections was limited to ten percent of the quantity destined for the campaign.

6 Perhaps with the exception of post-communist parties - i.e. the Left Democratic Alliance (Sojusz Lewicy Demokratycznej - SLD), the Polish Peasant Party (Polskie Stronnictwo Ludowe - PSL) and, to a lesser extent, the Democratic Party (Stronnictwo Demokratyczne - SD) - favoured by their large memberships, property and post-nomenclature business links.

7 This distrust and suspicion of the word 'party' still holds true today. Thus none of the titles of six main Polish political 'parties' contains the word party. Not even PSL, as its Polish name uses the old Polish word of 'stronnictwo' and not 'partia'. 
In terms of control, there was only a constitutional obligation on parties to present a financial declaration, as well as to publish it. Other than that no real control over the financing of parties was established and, in particular, a proper framework of sanctions was lacking.

\section{2001-2015}

It was only in 2001, with the introduction of a new electoral law which once again (for the third time) changed the electoral system, that important reforms in terms of funding were introduced in the PL. Indeed, it was really at this time that a predominately public regime of party financing was established and a proper system of financial control introduced. And these two pillars of Polish party regulation have been maintained, with very minor changes, ever since. Below we examine the content of the current regulation, with special focus on the public and private funding, and on controls and sanctions.

\section{Public funding}

In Poland it is possible to distinguish two different types of public subsidies. The first is the reimbursement of electoral expenses (through the so-called 'dotation'), with ECs as the main beneficiaries. Only ECs which obtain at least one deputy, either in the Sejm or the Senate, have the right to claim such electoral reimbursement, the total amount of which is calculated taking into consideration the total amount spent by all ECs during the campaign divided by 560 (i.e. 460 deputies +100 senators). However, because this type of state aid has only the goal of compensating parties for their electoral expenses, the amount of money received by a particular EC cannot exceed the amount spent by the same EC during the electoral campaign. The problem which arises is thus when an EC obtains a disastrous result after a rather expensive electoral campaign, which is what happened to most of the Polish political parties after the 2011 parliamentary elections. In fact, with the exception of the two main political parties - Civic Platform (Platforma Obywatelska PO) and Law and Justice (Prawo i Sprawiedliwość - PiS) - the other 
three political formations with parliamentary representation (Your Movement - Twój Ruch - TR ${ }^{8}$, PSL, and SLD) did not manage to have their electoral expenses covered ${ }^{9}$. As a result, it is possible to conclude that, at least for PO and PiS, their respective 2011 electoral campaigns were free of costs.

It was for this reason, and taking into consideration that these two parties (together with the other three: RP, PSL and SLD) got all the public subsidies, that some academics/experts began to question the utility of the so-called 'dotation'. Their argument was that if partisan ECs can only finance their electoral campaigns with money from their electoral funds, to which they dedicate most of their state aid, then the electoral reimbursement of their campaign expenses does not make much sense as, at least for parliamentary parties, the state ends paying for twice the same thing (i.e. campaign) ${ }^{10}$. Moreover, the current system of electoral reimbursement has also been called into question for encouraging parties to increase their expenditures almost to the infinite. Thus, if the total amount to be reimbursed is calculated on the basis of all ECs' expenditures, then the major parties have no reason to restrain their expenditures as they know that most of them will still be reimbursed (as was the case with PiS in 2011).

While there is no 'dotation' for electoral expenses incurred during presidential or local elections ${ }^{11}$, the Electoral Code (KW, after the Polish

8 Initially known as Palikot's Movement (Ruch Palikota - RP).

9 Interestingly enough, both $\mathrm{PO}$ and $\mathrm{PiS}$ got almost the same amount of money (around 30 million PLN), despite the fact that the former got almost ten percent more votes than the latter. This was because PO's campaign was less expensive than PiS's.

10 Moreover, it helps parties to divert most of their income to other 'organizational' aims, exponentially increasing their budgets and definitively creating a comparative discrimination in relation to extra-parliamentary parties and ECs.

11 Because expenditure limits in local elections are calculated on the basis of the number of candidates presented, big parties are encouraged to present candidates even in those districts where they know they do not have a chance of winning (e.g. PSL in Warsaw, Cracow, etc.) as this will allow them to increase their overall expenditure limit, with the consequences this may have for the equality of political competition (especially in second round elections). 
acronym) provides for the reimbursement of electoral expenses during the European Parliament (EP) electoral campaign for those ECs obtaining at least one MEP. In this case however the total amount of the subsidy is calculated on the basis of the number of votes cast, with the idea of encouraging as many voters as possible to go to the polls and cast their votes. The reason behind the lack of 'dotation' for the local and presidential elections can be found in the minor role played by parties in these elections. Thus, while only ECs, not parties, can present candidates for President of the Polish Republic, parties (with the exception of PSL) tend to play a secondary role in local elections, especially outside the big cities. Indeed, and as I have been repeatedly told, even in those cases where popular candidates have links to parties they prefer to play the role of 'independents'.

One important consideration to be made here is that while all ECs are entitled to receive reimbursement of their electoral expenses on the basis of the above-mentioned calculations, the truth is that only partisan ECs receive this type of subsidy. This is because, first of all, in most cases only partisan ECs manage to obtain representation, and secondly because ECs cease to exist immediately after elections ${ }^{12}$. The only way these types of ECs would be able to obtain the so-called 'dotation' is if they spent more money than they had at the beginning or during the campaign. However, this is very exceptional as non-partisan ECs do not usually have access to banks loans, which is the main way political parties finance their campaigns. In other words, while in the case of partisan ECs it is the party which receives the subsidy, in the case of non-partisan ECs obtaining mandates the electoral reimbursement is destined to finance charitable goals, rather than the EC itself. In this way, the purpose of the electoral reimbursement (i.e. compensation for electoral expenses) is distorted. The same would happen in the event an EC gets sufficient mandates to obtain the right to receive a larger

12 This was the case of Włodzimierz Cimoszewicz, a former prime minister and currently senator. This clearly introduces an element of unfairness and discrimination between partisan and non-partisan ECs. 
quantity of money than that actually spent during its electoral campaign. This will again create a path to a surreptitious way of financing charitable institutions, something for which the 'dotation' was not established in the first place. A possible solution could be to pay the 'dotation' to those people/entities contributing to the campaign of the 'winning candidate(s)'. But, as most of my interviewees pointed out, this would create even more problems.

Another way distortion takes place is when an EC does not manage to pay the debts contracted during the electoral campaign and does not manage to obtain any mandates. In that case, its bills remain unpaid, leading to a kind of 'surreptitious' financing of politics, even by private companies. And this is something that, as we already know, is totally forbidden by the KW. As a result, some people (e.g. Adam Sawicki) have been calling for an end to the 'dotation' system, limiting the public financing of parties to the second type of public subsidies, i.e. subventions.

At the end of the day, and as was recognized by all my interviewees, what really decides about the survival of parties is the so-called 'subvention' which political parties themselves receive from the state in order to cover expenses for their ordinary activities ${ }^{13}$. This subsidy, which is guaranteed to all political parties which obtain at least three percent (six percent in the case of coalitions) of the votes during the most recent legislative elections to the Sejm, is calculated 'on a gradual digression basis pro rata to the total number of valid votes cast on district lists of candidates for deputies of [a certain] party or electoral coalition' (Art. 29 of the KW; for more details see Walecki, 2005). As a result, there is always a preference for small parties in the distribution as the first votes necessary to reach the threshold are considered to be always more expensive. In clear contrast to the so-called 'dotation', paid just once after the elections, the 'subvention' is paid annually once the PKW (National Electoral Commission) has accepted a party's annual financial declaration.

13 For a comparative perspective, see Casal Bértoa and Spirova (2013). 
As most interviewees have remarked, the change from a five to three percent threshold responded to two different needs: namely, democratization and security. With respect to democratization, the idea was to allow relevant extra-parliamentary parties to continue with their representation activities, as expressing the interests of significant sectors of Polish society. On the other hand, as regards security, the idea was to increase the continuity (at least until the next elections) of political parties in an otherwise rather unstable party system, where even a party/ coalition with more than 30 percent of the votes could not be sure that it would make it into the next parliament. In practice, with the exception of the Labour Party (UP) in 1997; the Freedom Union (UW) in 2001; and Social Democracy of Poland (SdPl) in 2005; no other party has managed to be located between the electoral and the payout thresholds.

In addition to these two types of public subsidies, Polish parliamentary groups also receive state financial aid. This is guaranteed to groups of deputies, groups of senators, and a mixture of both (properly called a 'parliamentary group'). Because these subsidies are not designated for the parties themselves, but rather exclusively for the administrative functions of the above-cited groups (e.g. hiring administrative staff, purchase of materials, organization of meetings, etc.), they are not included in parties' financial declarations. These subsidies are reserved within the budget of both the Chancellery of the Sejm and the Senate, which also take care of their distribution and strict control (through external auditing when necessary). Although each of the above-mentioned groups may also get money from their own members according to their internal rules, only the above-cited subsidies are subject to the control of the Presidents of the Sejm/Senate respectively.

In any case, and as reported by all the parliamentary members interviewed, the amount received by parliamentary groups in this way is considered to be right, just, and even 'too scarce'.

Although most Polish political parties (e.g. PiS, SLD and PSL) agreed with the current system of (predominant) public funding, some considered that parties' financial dependency on the state 
can be considered as a 'very easy solution', leading parties to worry about their popular support only every four years. Thus, Solidarity Poland (Solidarna Polska - SP) considers that parties' dependency on public subsidies not only hinders partisanship, but also decreases parties' legitimacy in the eyes of the public, especially in the current times of economic crisis. For this reason, and in order to address both problems, this new political formation has presented a two-fold proposal: on the one hand an increase in the limits to individual donations ${ }^{14}$, albeit in relation to the Polish average income; and on the other a cancellation of the reception of public subsidies, at least until the end of each current legislative period. Interestingly enough, SP was not opposed in principle to the receipt of state aid, although they considered that this should be a matter of discussion for the new 2015-2019 Sejm. Most parties (e.g. SLD) not only opposed the reduction of public subsidies, but considered SP's proposal to be simply 'electoral populism' as this formation, created by a split from PiS, is not currently entitled to public subsidies.

At the time of my stay in Poland, and mainly due to the public debate generated by an article authored by Dominika Wielowieyska in Gazeta Wyborcza, calls by the Prime Minister for a suppression of public funding were constantly in the media. Some people in the streets even suggested that PO's initiative and Gazeta Wyborcza's publication had been orchestrated. Others, like Józef Stefańczyk (PSL), thought that PO's 'populistic proposal' was aimed at hiding the problems of the party in Warsaw, Elbląg and in the Silesia region, as well as its continual decline in electoral support. All in all, the possibility of success for such proposal was minimal, even if $\mathrm{PO}$ and RP together had a legislative majority, as it would lead to the break-up of the coalition government between PO and PSL.

14 This is also the opinion of Dominika Wielowieyska, journalist of Gazeta Wyborcza, who notwithstanding her total support for public funding, considers that such a proposal would encourage/increase the involvement of citizens in politics. Something seems clearly needed in a country where most party leaders have been active on the scene for 30 years or more. 
Thus, with the exception of $\mathrm{PO}^{15}$, during the time of my research all Polish political parties were in favour of public funding. The main reason for opposing the elimination of public subsidies was the fear that political parties may become dependent on private interests and, therefore, party corruption would increase. A second reason refers to the fact that the elimination of public subsidies would 'cartelize' the party system around the current players even more, clearly favouring bigger parties, which could obtain larger donations at the expense of smaller parties, whose chances to attract financial support is more limited. Similar arguments have been stated by parties when asked about the need to reduce the amount designated for public subsidies. This was also the opinion of the two journalists interviewed. In their opinion, the fact that parties receive so much money from the state constitutes a clear deterrence against party corruption, especially in the case of big parties, for whom the loss of the annual subvention would be electoral suicide $^{16}$.

Still, some parties (e.g. PSL), even if they consider that a better explanation is needed for why parties (a necessary condition for democracy) should be funded by the state, could be open to PO's idea, but on one condition: namely that all parties would surrender their savings ( $\mathrm{PO}$ is thought to have up to 50 million PLN in their 'strongboxes'), so that a new beginning (i.e. 'financial tabula rasa') could take place.

Interestingly enough, RP has taken a position in favour of public funding, but not of the current system of public subsidies. Thus, this new party, founded by a multimillionaire former member of PO (Janusz Palikot), repeatedly proposed that parties should be funded with voluntary contributions made by citizens at the time of filing their personal income tax (PIT) declarations. The idea is that each citizen

15 It should be noted here that PO's original program already contemplated the elimination of public subsidies. Later it simply 'joined the club of subsidized parties' and continued to benefit (especially after 2005) from state aid.

16 PSL's financial problems, although not due to corrupt practices, are a clear example of the risks parties undergo when they lose their right to state aid. 
could give one percent of his/her PIT to his or her preferred party ${ }^{17}$. This would certainly make it possible to subsidize parties yearly (and not only every four years), changing the way political parties organize (i.e. not mobilizing only at election times). As a result, parties in opposition might have more control over the government, or the parties in government could be rewarded for their good policies. Moreover, such a proposed system would not discriminate between parliamentary (five or more percent of votes), relevant (three or more percent of votes) or small (one or less percent) parties, and even allow for the creation of new political formations, which could be supported almost from the very beginning (i.e. after their first year), without the need to wait until after participating in elections.

Together with its proposals to limit the terms of politicians' mandates (including even party leaders) to two legislative periods (a maximum of ten years), TR believed that its proposals would bring citizens closer to politics. The main goal behind this is that politics should be understood as a vocation, and not so much as a profession or a simply a step toward a future career in other public (more lucrative) institutions (public companies, organs, etc.). For these reasons, in the mind of TR any measure that would help to increase the voter turnout, creating paths for new (and possibly young) faces in politics, is more than welcome.

Most political formations were opposed to TR's proposal, for various reasons. First of all, most parties (e.g. SP, SLD) consider that such type of party financing would only benefit 'rich voters', enabling businesses to influence politics, therefore hindering both the financial and political independence of parties. This would certainly reverse the current trend, devolving the country back to the widespread party corruption of the 1990s. Secondly, it would discriminate against certain voters (e.g. peasants do not pay PIT). Thirdly, according to the opinion of the two post-communist parties (SLD and PSL), such a proposal

17 Because of the criticism regarding the fact that with that at one percent parties could receive a higher amount of money, RP (later TR) changed its proposal: it was just 0.7 percent when I finished my research. 
would create a conflict with the constitutional principle of 'secret voting, as taxpayers making party designations in their annual PIT declarations would be easily identifiable, leading to possible reprisals (social discrimination, job losses, etc. ${ }^{18}$. Fourthly, PO is afraid that such a solution would only favour parties with a core of electoral supporters: mainly SLD and PSL, but also PiS, while it would not so much benefit PO or the initiator of the proposal (TR).

Both PO and PSL's positions are understandable, as while the former has a relatively low number of members and lacks a real core of electoral supporters, the latter would suffer from the fact that its electoral core (i.e. peasants) would not be able to make contributions to the party. SLD's take on the issue is surprising to say the least, as with around 73 thousand members (Biezen et al., 2012: 50) and a core of nine or ten percent of supporters, it could easily collect some 20 million PLN, up to four times what the party currently receives. Nonetheless, and in part because this could lead the state to excessive public debt, SLD prefers to support the general interest rather than its own.

During my fieldwork in Poland, I floated an alternative solution: what if, instead of identifying the party to which a person wishes to assign a certain percentage of his/her taxes, such percentage would be used to determine the total amount to be distributed among parties? The reasoning behind this is that it would not only make it impossible to identify donors, but would also increase the legitimacy of public funding, as parties would receive only what the citizens voluntarily determined.

To some however this would only make the current system more complicated, even increasing the administrative costs of the whole process, without changing the fact that the funding would continue to come from the same source: the state. Moreover, this would certainly go against one of the main principles of tax collection and distribution,

18 TR maintains that if someone gives financial support to a party, this does not mean that he/she will subsequently vote for it. He/she may have different intentions; weakening the opposition, etc. 
i.e that citizens are not directly permitted to decide on how much and on what public money should be spent. Others (e.g. SLD) opposed it as it would certainly increase the amount of money designated for the parties from the current 60 million (approximately) to more than 125 million PLN (even in the case where the percentage included in the PIT declaration would be just 0.25 percent), leading the state toward bankruptcy. Faced with the counterfactual alternative situation, that is that very few people would be willing to publicly finance parties, most party representatives pointed to the essential role parties play in current democracies, justifying the necessity to continue the current system of public funding. It was feared that anything to the contrary would constitute 'democratic suicide' (SLD).

There is a general opinion that the current system of public funding, which benefits only parties with more than three percent of the votes, makes it difficult for new or small parties to enter the political arena. Thus it is not surprising that most existing parties oppose the proposal to reduce the payout threshold to one percent. In the opinion of SLD the current payout threshold of three percent is already too low, allowing parties with roughly 500 thousand votes to take advantage of state aid. Moreover, the appearance of TR, which spent less than two million PLN and made it into parliament a few months after its formation, clearly proves that breaking the so-called 'Polish cartel' is not a matter of just finances.

\section{Private funding}

As we have already seen, from 1990 until 2001 parties could not only obtain money from private companies, but also undertake certain types of business activities or make profits from their own property. Moreover, even if donations from public and foreign companies were forbidden, Polish PL (in both 1990 or 1997 versions) allowed for both cash and anonymous donations.

After 2001 none of these private sources of finance are allowed, with one exception: parties can profit from the sales of their properties. 
It should be borne in mind that the 2001 legislative reform was passed by AWS, with the support of UW, i.e. by two post-Solidarity parties intending to diminish the original financial advantage of the post-communist parties (mainly SLD and PSL, as SD soon withdrew from active political life $)^{19}$, which had inherited huge amounts of property from their predecessors from the communist period (i.e. the Polish United Workers' Party - Polska Zjednoczona Partia Robotnicza - PZPR; and the United People's Party - Zjednoczone Stronnictwo Ludowe ZSL). This is basically why the original $1997 \mathrm{PL}$, passed mainly with the approval of SLD and PSL, did not contain any dispositions of this kind. Still, because the prohibition against taking financial advantage of property by parties (except for their own use or sale) would have affected not only the above-cited post-communist parties themselves putting their finances in peril - but also enormous numbers of people living in such properties, the PL (in its 2001 version) provided for a grace period of one and a half years (until autumn 2002). This allowed not only for the selling of much of the property ${ }^{20}$, but also for the relocation of tenants, shops, etc.

It was at this time (2001) that the public collection of money was forbidden, both for parties (as per the $1997 \mathrm{PL}$ ) and for ECs during elections (the 2001 Electoral Law (KW). Interestingly enough, the 1990 Presidential Elections Law permitted both foreign individual donations and public collections for ECs during the presidential election campaigns until 2006, which was then changed by the new KW in 2011. However, it must be noted that since 2001 such types of collections were considered to be an anachronism, and above all were poorly viewed in the public eye as they were mostly identified with the possibility of accepting donations

19 SD continues to have important real estate as well as substantial benefits from businesses. Because it is not interested in participating in elections nor in receiving public subsidies, it does not have problems in presenting an annual declaration constantly rejected - in order to avoid dissolution.

20 It should not be forgotten, for example, that the PSL decided to invest all the money obtained after its 1993 electoral success into real estate. 
from private companies. Hence most ECs (except for two) did not make use of them during the 2005 presidential campaign.

It was also in 2001 that cash donations for electoral committees were forbidden and were also clearly limited for parties (to 15 times the minimum wage per year). As we will have the opportunity to examine later on, donations made by natural persons can only take place in the form of bank transfers, debit cards, or check payments.

\section{Indirect public funding}

Like its immediate predecessor, the 1997 PL guarantees parties the right to have 'access to public radio and television in accordance with the rules laid down in separate acts' (Art. 5). In a similar vein, the KW allows for the free broadcasting of campaign materials prepared by electoral committees on public television and radio. For example, in the case of legislative elections, candidates to the Sejm are guaranteed between 15 and 30 hours of national coverage and between 10 and 15 hours at the regional level on the Polish public television (TVP) and radio (Polskie Radio). However, only those electoral committees that have registered lists of candidates in at least half of the constituencies are entitled to free nationwide broadcasts (Casal Bértoa and Walecki, 2014).

In terms of tax exemptions, one of the most common types of indirect public funding, it is important to note that in Poland all parties are obliged to annually present a Business Enterprise Tax (CIT) declaration. However, because since 2001 parties cannot have any type of revenue income (no businesses, no rentals, etc.) ${ }^{21}$ and because they only spend money on their own activities, they do not really have to pay this tax. Parties are obliged, however, to pay VAT or property taxes.

It should also be borne in mind here that donations to parties are neither exempted from tax nor can be deducted from the donors' PIT,

21 They are not even allowed to lend their property for free, with the exception of public officials (e.g. deputies or local party officials). This was introduced in order to avoid parties taking advantage of payments of the 'community tax' (czynsz) paid by the 'free' tenants. 
as is the case in many other European countries (e.g. France, Portugal, Slovenia, etc.).

\section{Expenditures}

The 1997 PL makes an important distinction regarding the object of party expenditures. Thus, while parties' property (donations, membership fees, etc.) may be spent for either their 'statutory aims or charitable works', parties' money originating from the state (i.e. public subsidies or 'subventions') can only be spent to defray the costs of their 'organizational activities', but not for charitable goals.

Still, the fact that Art. 34a.1a, dealing with the rejection of a party's annual financial declaration, includes the expending of public subsidies on aims not connected with the party's statutory activities, seems to create a certain controversy on the permitted object of party expenditures. In fact, taking into consideration that the aims of a party are not always directly achieved through their statutory activities, it would seem that Art. 24 contains a better formulation of the permitted objects of party expenditures. Because at the end of the day there is always the problem of interpreting what the expression 'statutory aims' means.

Indeed, at the time of my interviews an important controversy erupted in this context. Between June 12th and 16th of 2013, Gazeta Wyborcza, one of the major Polish dailies, published a series of articles about how political parties spent their money. From the articles it followed that the governing at that time PO spent more than 700 thousand PLN for the pension schemes for their high-ranking members, PiS almost 1 million PLN on party leader Jarosław Kaczyński's private security, and TR and SLD spent a rather considerable amount of money in wine and restaurants, respectively. Other expenditures referred to hairdressers or suits for the MPs. The descriptions in the articles of important media and academic persons being financed by certain parties (usually the ones they were in favour of) was also the cause of a certain social scandal.

Interestingly enough, while for certain parties there is a clear concern with the sources of party finances, for others party expenditures are 
the 'mother of all troubles'. In this context, one of the main problems is that it is difficult to identify whether a certain payment is made out of a party's public or private money. ${ }^{22}$ Another problem is that the way political parties spend their money is not really regulated. Indeed, Gazeta Wyborcza's article raised a certain sociopolitical debate about the way in which political parties should be using their money, especially those funds coming from public subsidies. In this context, most parties (e.g. PiS, SLD, etc.) consider that party expenditures should be focused on programmatic material, expertise, youth schooling and training, etc., and not so much on items (e.g. alcohol, dresses, etc.) that may raise popular concern or suspicion. But while SLD would not be against an increase in PKW's control competences and sanction powers, $\mathrm{PiS}$ goes as far as to propose that 15 percent of public subsidies should be spent on the party organization itself, and the rest in research, training, expertise and in any other activities responding to the national interest, either at the local or regional level. In any case, party expenditures should be as open and transparent as possible.

Some have even proposed the establishment of a system of 'public bids' in order to avoid situations in which a party contracts services with companies belonging to party leaders/members or their close relatives, allowing the latter to garner significant financial gains. This practice has been contested in various ways. First of all, parties may have different interests, and what is cheap for one may be expensive for the other. In a similar vein, it could well be that if the cheapest option is always chosen, then it could easily happen that the service provided is not good or even worth the small price paid for it. Thirdly, in many cases it is a question of timing or convenience, rather than money. Finally, it is obvious that in most cases a party is not going to hire someone (mostly concerning experts, but not only) who is not ideologically close to the party; either because he/she may not properly understand the interests of the party or because they may be interested in harming them. At the end of the day,

22 This allowed one party treasurer in Elbląg to justify the purchase of the party leader's wife's dresses using party money. As it was supposedly done with money coming from individual donations, such deed was shameful, but not illegal. 
as Kazimierz Ujazdowski (a former AWS Minister of Culture) put it: 'politics is mostly art, and not so much a science'.

Other parties (e.g. PSL), experts and journalists prefer to leave the current freedom of action for parties in place and rely on public monitoring so that citizens, having a clear knowledge of how different parties spend their money, could later act consequently: namely by voting or not voting for that particular party. The idea is that if, for instance, a party spends a lot of money on hairdressers, those who see such an expenditure as illegitimate will withdraw their electoral support, perhaps leading (depending on the numbers) to both an electoral and financial crisis. At the end of the day, we should not forget that it is voters who, by their votes, are also financing their own parties. This may even lead to a real controversy within a party, as certain party members may be against certain types of expenditures ${ }^{23}$.

Still, for some parties (e.g. PSL) there should be a clear distinction between party expenditures of public subsidies and party expenditures of membership fees, donations, and any money coming from private sources. Thus, while the former should be strictly controlled, the latter does not necessarily have to be. Although, coming as it does from a party that has used patronage as one of its main resources to obtain popular allegiance and electoral support, such a statement should not come as a surprise.

For PO representatives, the problem is not so much about party expenditures in general, but about excessive expenditures during the electoral campaign. In this context, PO has repeatedly tried (unsuccessfully) to reduce the number of billboards employed at the time of elections.

\section{Party funding control}

The financial control of parties and electoral committees in Poland has clearly improved over time. Thus, while between 1990 and 1993

23 As most party members do not have any public function, they will not be endangered by the denunciation of his/her own party's illegitimate practices. 
the control of party finances was totally non-existent, following the idealistic principle of laisse faire (Casal Bértoa and Walecki, 2014), a formal system of control was introduced by the 1993 PL, which also introduced the current electoral threshold of five percent. Thus, the PL obliged electoral committees (but not parties) to publish their financial declarations in the press. Unfortunately however, the financial declarations were so simple that they could be printed on just one page of a newspaper. In addition, there were no sanctions imposed on those electoral committees which failed to publish their financial declaration. In such cases, the PKW, which was obliged to keep a copy of the newspapers in which financial declarations were published in its archives, could only insist that such declarations be published, but no sanctions were provided for non-publishing. In any case, parties themselves were exempt, as the PL did not contain any dispositions in this regard.

After the approval of the new PL in 1997, and up until the 2001 legislative reform, parties had the obligation to send their financial declarations to the Warsaw District Court (Sad Okregowy w Warszawie), which simply made a record of it by act, but was not obliged to publish them (neither the acts nor the declarations). In those cases where a party did not send in its declaration, the court was obliged to send a reminder and, only in the case where a 'rebel' party still failed to fulfil its obligation the party was to be deleted from the Party Register. Still today there continues to be a lack of an efficient system of control, as well as a framework for the application of sanctions, with respect to party finances.

The 2001 legal reform nevertheless changed this panorama. In clear contrast to other European democracies, where the financial control of political parties is a task for the Constitutional Court (e.g. Portugal) or the Court of Auditors (e.g. Spain), in Poland the National Electoral Commission (PKW) is the designated organ in charge of control tasks. The reasons for this state of affairs can be found, first of all, in the fact that it has always been one of the most (if not the most) impartial organs of the state, clearly guaranteeing the neutral treatment of political parties. The fact that it is independent from any other state organ - it even has its own budget - and is composed of nine judges 
from the highest courts in the Polish Republic, further guarantees its impartial, apolitical, and totally neutral character. Indeed, the PKW is composed of three judges of the Constitutional Tribunal (Trybunat Konstytucyjny - TK), three judges of the Supreme Court (Sąd Najwyższy), and another three of the Administrative Court, all appointed by the President of the Republic based on the proposals of the Presidents of each of the above-mentioned Courts, which are the only ones also with the capacity to 'denounce' their appointment. Similar to other high officials (see the section on the Polish Constitution), the members of the PKW cannot belong to any political party.

Secondly, it should also be noted that, while originally charged with the control of the fairness of elections and electoral campaigns, after 2001 the PKW was also given the task of controlling party finances. It is important to note here that this has taken away much of their time from their original activity, that is, the control of elections and their financing. But it should not be forgotten that, even if parties are the main contenders in elections, parties are not the only ones to do so (e.g. non-partisan electoral committees also participate). Moreover, eighty percent of the registered parties, thus those financially controlled by the PKW, do not take part in elections.

Taking into consideration that $\mathrm{PKW}^{\prime} \mathrm{s}$ main commitment is the control of elections, and bearing in mind the constitutional principle of the financial transparency of parties, it is necessary to point out, before having a look at the control mechanisms employed, that in principle the PKW exerts a general control on both income (of any type, as it can always be used for electoral purposes) and electoral expenditures. That is, parties' expenditures in relation to their own organizational activities fall outside the financial control of PKW, except for those parties receiving state subsidies. Indeed the public nature of such money requires that is spent both 'transparently' and legally (see below).

Although the main task of PKW is to ensure that the financial activities of parties and electoral committees have taken place in accordance with the law, PKW's first and main task is to publish the financial declarations of both parties and electoral committees. It is only then that the PKW 
undertakes the task of examining the declarations to see if they are in accordance with the actual facts. For that, a control of the attached documents follows, aimed at analysing to what extent they coincide with the financial activities reported in the declaration.

The result of such an examination can be two-fold. Firstly, it may well happen that the PKW discovers that the financial declaration is not accurate, as it contains formal mistakes. In this case, for instance when a party has failed to properly sum up its income, or the expenditures reported in the declaration contain errata, the PKW simply proceeds to correct them, archiving the corrected version of the declaration for those interested (e.g. journalists, citizens, etc.). Unfortunately, there is not currently an obligation to publish the corrected version of the declaration (just the original one).

Interestingly enough, most of the instances when an inaccurate declaration is presented are due not so much to malicious intentions on the part of parties and electoral committees, e.g. as if they had the intention to hide something, but rather to the lack of competent professionals in charge of fulfilling the minimum accounting obligations. Indeed, most of the financial declarations which contain formal mistakes are done by amateurs working for small parties, which lack the resources to hire appropriate professionals in the field.

Secondly, and definitely more importantly, the declaration may be rejected. The PL contains seven very straightforward reasons according to which the parties and electoral committees financial declarations should be rejected. These are:

1. a party undertook business activities;

2. receipt of money from public sources;

3. receipt of money without registration in the bank statements;

4. receipt of money from illegal sources;

5. spending money on the electoral campaign not from the electoral fund;

6. spending money from the electoral fund without bank receipts or billings;

7. spending more money than allowed. 
In the absence of any of these seven reasons, the declaration will always be accepted (even if formally inaccurate). Because the consequences of rejection for parties receiving public subsidies are very severe (i.e. loss of state aid for up to three years $)^{24}$, leading in some cases to the party's disappearance from the political scene, the interpretation of the above-cited dispositions and the way the PKW has applied them have been the object of frequent controversy. However, the Supreme Court has confirmed again and again that the dispositions contained in the PL (which are the same as those for the ECs in the KW) should be interpreted in a dichotomous way. That is, what the PKW needs to do always is simply to examine if there has been an infraction or not, leaving aside any possible evaluation/interpretation regarding the amount, reasons behind, deception etc. Thus, for example, if the PKW observes that a party has received money from a legal person, the sanction imposed will be the same (i.e. loss of public funding) regardless of whether the quantity received was fifty PLN or five million PLN, or whether the party really asked for that money or the party treasurer did not realize that it had received it in the bank account, and spent it instead of returning it.

A similar jurisprudence has been adopted by the Supreme Court in relation to the obligation of parties to present their annual financial declaration. The consequence (i.e. de-registration) is the same independently of there was a delay (whether one day, one week, or one month) or whether there was no presentation at all. The idea is that because the principle of transparency has a constitutional rank infusing all regulations on the topic, the reason why a party's financial declaration is not presented on time is totally irrelevant. So excuses of the type 'our treasurer was ill', 'we didn't know about such obligation', or 'we only received two hundred PLN', etc. will never be considered by the PKW.

24 The rejection of an EC's financial declaration is simply the loss of the electoral reimbursement (i.e. dotation) and, if applicable, also the devolution of the amount of any money illegally spent. 
Echoing a complaint made mostly by small parties, GRECO $^{25}$ has repeatedly criticized Poland for a regulation that dissolves parties (and, therefore, does not allow them to present candidates in elections $)^{26}$ for a simple delay of one day in presenting their financial declarations. Polish authorities have defended themselves by noting the constitutional rank of the transparency principle underlying the entire party funding regulation. Moreover, the fact that such sanction is relevant only for those parties receiving public subsidies (as any successor party will not be allowed to take the money of its predecessor), but not for others, somehow diminishes both the scope and severity of the sanction.

Moreover, and notwithstanding the above-mentioned criticism, the majority of the most important actors (e.g. the main parties, the Supreme Court, PKW personnel) consider it as a very good system, as it guarantees both impartiality as well as objective application. It guarantees impartiality because, due to the mechanical application of the rule, no party can complain of discrimination. It guarantees objective application because the lack of presentation is punished equally, independently of whether the treasurer was ill or on holidays. If the PKW were able to punish the one violation in a more lenient way than another, then the PKW would be accused of favouring a certain party. And there is a very short distance between such an accusation and an accusation that the PKW does the same during elections, thus manipulating the electoral results.

As a result, and taking into consideration what has just been said, it is far more advisable for a party to present their annual financial declarations on time, even with formal mistakes (although none of the seven cardinal errors listed above), than to fail to present them. However, this approach presents a real problem in the case of small parties because, as they care

25 The Group of States against Corruption (GRECO) is the Council of Europe anti-corruption body.

26 Although the Polish regulation (both the Constitution and the PL) allows for the existence of non-registered parties (with propagandistic aims only, perhaps), it is only through registration that legal personality, and therefore the right to participate in elections, is guaranteed. 
mostly about not losing their legal personality, they will not put any great effort into presenting flawless declarations. And because there are no real sanctions for filing formally defective declarations, the PKW is then obliged to do a significant amount of extra work trying to spot all these formal mistakes, which in any case will be included in the financial declaration published in the PKW website.

Because donations made by natural persons can only take place in the form of bank transfers, debit cards or check payments, bank statements are considered to be the most powerful weapon of control in the hands of the PKW. In addition, because banks are strictly controlled by the state itself, bank statements are considered by the PKW to be a perfect reflection of what happens, at least financially, in real life. The only exception to the general rule that parties' financial sources need to be accumulated in a bank account refers to parties' 'local headquarters', where donations and fees can be made in cash on the condition that they are employed by the same local headquarters in the funding of their ordinary activities; for instance the organization of small meetings, purchase of water, stamps, etc. The idea is that forbidding the use of cash in these instances would not only make parties' activities difficult, as they would have to send the money collected to rent a place for a meeting to the central account of the political parties, and then ask the party treasurer in Warsaw for consent for a bank transfer from that same account, but would also waste the PKW's time in the control of small and unimportant amounts of money.

This is not to deny, however, that some party payments can be made in cash. The requirement, though, is that any cash withdrawal needs to be registered in the bank statements for the PKW. Indeed, if parties were not allowed to make cash payments, their ordinary life would certainly be interrupted without reasonable justification. At the same time, this is also not to say that parties are not obliged to keep all the bank statements of their transactions (including those in cash).

While electoral committees are obliged to present, together with their declaration, all bank statements and bills as well as, if possible, a copy/ model of the electoral leaflets, billboards, cups, etc. made; political parties 
are not obliged to present the receipts, just the financial declarations. Both declarations are then checked by an independent auditor appointed by the $\mathrm{PKW}^{27}$, following the $\mathrm{PKW}^{\prime}$ s instructions ${ }^{28}$. Still, as we will see later on the $\mathrm{PKW}^{\prime}$ s control over parties' ordinary expenditures is less strict than over ECs' electoral expenditures. In the latter case, the PKW controls not only whether the money has been received legally (i.e. not from banned sources or in prohibited ways), but also if it has been spent according to the law (i.e. not more than the maximum allowed, or in non-electoral activities, etc. $)^{29}$.

The PKW's financial control takes place only after the presentation of the declaration, and not before (e.g. during elections), or at the time certain activities (e.g. electoral campaigns) take place. Moreover, it is a very formal control, consisting just of a comparison of the documents provided (bank statements and bills, if applicable) and the financial declaration presented. It is thus not surprising that PKW's control is one of the fastest in Europe ${ }^{30}$. This is because it is simply a documentary control, not an inquiry into the underlying facts, owing mainly to the fact that the PKW does not have the competences nor, more importantly, the means to do so. This is not to say that a proper factual control cannot take place, but for that the PKW needs to make use of the information provided by other state organs ${ }^{31}$, which have an obligation to assist

27 One of the problems here is that as most good auditing companies tend not only to be expensive but reluctant to get involved in politics, As a result the PKW ends up hiring not necessarily competent or well prepared auditors, which obviously will have consequences on the adequate control of party finances.

28 Which do not seem to be always clear or even transparent. Thus, the PKW refuses to specify such directives to Batory Foundation's controllers at the time of the different election controls by the Batory Foundation.

29 Payment of a partisan EC's debts constitutes the only exception. Then the control takes place at the time of the examination of the parties' financial declarations.

30 As required by the periods established in the KW and the PL, PKW's control can take no more than six months, allowing for an up-to-date publication of parties' financial declarations, something that does not take place in other countries like Spain, Portugal, etc., where the control authority is very often late.

31 It is important to note here that the PKW is only allowed to ask for information 
the PKW with its inquiries. In fact, there have been cases of factual controls. For example, an electoral committee that, owing to having obtained a good result was therefore entitled to a substantial monetary reimbursement, created a falsified bill from a printing house in order to get more money than it had really spent. ${ }^{32}$ Moreover the electoral committee didn't present any bills for hanging the billboards, renting the places where they were alleged to have stood, nor even a copy proving that the billboards ever existed. This led to suspicion on the part of the PKW, which requested the Tax Office (Izba Skarbowa) to check on the printing company. In a short period of time the Tax Office discovered that the printing company was supposedly located in an obscure village under very precarious conditions. Once located, the Tax Office proceeded to ask for the different bills (printing, paper, etc.). Soon it became clear that there had not been any printing of electoral billboards, and the reimbursement for the electoral committee was cut down to the amount it had really spent during the campaign. Interestingly enough, there were no sanctions imposed on the electoral committee, as it had not received any money illegally ${ }^{33}$. Notwithstanding that, however, penal sanctions were available for any crime committed by individuals relating to 'false testimony', 'tax infractions', 'forgery', etc.

However, the above was an exceptional case, as in most cases it is impossible to use the information that state institutions like the Tax Office, Court of Auditors (Najwyższa Izba Kontrolii), etc. could provide. The main reason for this is the different time frames. While the PKW has to decide whether to reject, or not, the financial declarations of parties

from Ps \& ECs, as well as state organs, but never from private natural or legal persons. For the latter, collaboration with the public prosecutor is necessary.

32 It should not be forgotten here that the amount of the electoral reimbursement can never exceed the amount of money actually spent during an electoral campaign.

33 According to the KW, the reimbursement will be cut by three times the amount of money illegally received, but only in those cases when an electoral committee receives money from illegal sources. and not when the money 'spent' didn't exist in the first place, like in this case. 
and electoral committees rather quickly (less than six months) ${ }^{34}$, most state organs employ different (larger) time periods; for instance up to five years in the case of the Tax Office, and in other law enforcement agencies from five to ten years, etc.

Because the PKW's control is mainly formal in nature, it is possible that certain 'non-registered' operations (e.g. no bills, no bank statements, etc.) will circumvent the process. Thus, if a party and a printing house share the same interests (i.e. performing a job without declaring it ${ }^{35}$, or not performing a job and declaring it), there are only two ways by which the PKW can come to know of it. Either someone reports the incident, or that a model/copy of the job falls into the hands of the PKW. At the end of the day we should not forget that ECs have an obligation to send to the PKW a copy/model of all their electoral materials. However, the problems arise when, for example, a party and a printing house agree to print 2000 leaflets, but include only 1000 in the bill. In such a case, the only way for the PKW to discover such fraud is:

a) thanks to the control of the Tax Office (e.g. the bill for the paper/ ink does not coincide with the bill for the printing). But they can only detect this if the difference is huge. If not, the printing house can say that the missing paper/ink was part of waste. Even in such a case it may well be that the party is not punished, as it will not be immediately obvious that such paper/ink was employed in the printing of leaflets;

b) due to intra-party conflicts, i.e. someone from the party itself reports it to the PKW. At the end of the day, big operations (e.g. billboards, huge numbers of leaflets/cups/caps, etc.) will be difficult to hide and many people will know about them.

34 So if the declaration is presented at the end of March, PKW has to take a decision before the end of September. Before it used to be just four months!

35 In a similar vein, and with the intention of going around the legal prohibition of using electoral materials that do not directly come from the parties, a candidate may use his/her allocated money to print 500 leaflets while asking the same printing house to print an extra 500 paid from his/her own pocket. The same candidate could also ask the printing company to issue a bill for half a price, then half is paid officially, while the other half is paid 'under the table'. 
Indeed, there have been cases when someone on behalf of an EC has signed contracts and paid for services that were never carried out, which could lead to the rejection of the post-electoral financial declaration by the PKW, and which have been reported less than one month after the elections. Thus the fact that during elections many people (not only party members, but also volunteers) collaborate helps the PKW to maintain a certain practical control. Interestingly enough, the Batory Foundation's controllers complained that in some cases, and after receiving anonymous phone calls reporting certain wrongdoing, the PKW was the entity to make a formal complaint at the police station. This seems to contradict the assertion that the PKW is always encouraging people to report any illegal activity on the part of parties during elections. Obviously, in many other cases there are problems with timing. If the denunciation takes place once the post-electoral financial declaration has been accepted by the PKW and the money for the 'dotation' paid, the party will remain unpunished and the only possible (criminal) sanctions would relate to the person(s) responsible for the illegality.

In the case of illegal financing of electoral campaigns, the responsibility falls on the person whose signature is connected with the illegal activity/ payment. Thus, even if someone (party member or not) accepts (voluntarily or involuntarily) an illegal payment, if the person in the party responsible for the financing of the campaign hasn't submitted his/her endorsement with his/her signature, then such person is not considered to have any responsibility for the deed(s). This is not to say that there are not cases when the party knows/encourages/allows a candidate to do something illegal under his/her own responsibility.

This is what happens in the case of 'negative campaigning'. Because in Poland this type of campaigning is formally treated in a similar fashion as 'positive campaigning', except that nobody wants to be identified with such negative campaigning. Hence both parties and electoral committees are tempted to collect funds for such type of campaigning in an illegal fashion. One way to do this is for an EC to ask for a service 
that costs 1000 PLN and register that it is has paid 5000. This allows frees up 4000 PLN for the negative campaigning.

A contrary scenario (i.e. that a party or electoral committee hires a service that costs 5000 PLN but pays only 1000 for it) can also take place, especially in order to avoid the maximum expenditure limit established by the KW. In such a case the control of the Tax Office on the person/company providing the service is essential. Such control will take place not in order to avoid electoral fraud, but tax fraud. Still, the consequences will be the same. Indeed, most people are afraid not so much of the PKW, but of the Tax Office increasing the reach of its financial control of parties and electoral committees, even if by indirect means.

But the fact that the PKW's control is mostly formal clearly undermines the reach and effectiveness of such control. Adam Sawicki, who had the opportunity to work for the Batory Foundation at the time of the 2005 presidential, 2006 local, and 2009 EP elections, pointed out some examples. Indeed, and this was also pointed out by many other interviewees, minor wrongdoings may escape the PKW's control because a party or electoral committee may opt for destroying certain bills paid outside of the banking system. Moreover, the fact that two elections are close to each other (e.g. 2005 presidential and parliamentary elections) also allows for certain 'financial engineering. This allowed Kaczyński's electoral campaign in 2005 to get away with the fact that he had exceeded the expenditure limits. Furthermore, Andrzej Lepper's financial declaration was accepted despite the fact he had a lot of unpaid bills with the security company in charge of providing security, transport, etc. for his campaign. Another interesting case was that of Democratic Party's (Partia Demokratyczna - PD) presidential candidate, Henryka Bochniarz, who granted herself (as an electoral committee) a loan after the elections in order to pay for some of the campaign bills. Currently this is not possible as the KW requires that the financial declarations identify all donors, which can only be natural persons and can only contribute up to a certain amount. However, this was not the case in 
2005, which made it possible for even just one person (or even a mafia) to finance an entire electoral campaign.

Another problem derived from the above-mentioned formality is that in the event a mismatch is discovered between what a party declared and what seems to have really happened, it is the PKW that will go back to the party and ask if what it has discovered is true. However, if the party totally denies it, the wrongdoing will not be sanctioned. This happened in 2005 when PiS said that it organized four concerts, but the company organizing the concerts for PiS presented a bill for twelve. The PKW asked PiS's electoral manager about it, but he denied it and no further actions were taken.

This has led some to think that the PKW is only interested in controlling whether parties and electoral committees get money from illegal sources and whether they spend more than what is allowed for each particular election, without controlling other indirect ways of illegal funding (e.g. unpaid bills) and/or excessive expenditures (e.g. destroyed bills).

Although the current status of the financial control of parties is certainly much better than the previous one (i.e. before 2001), there are still certain issues that could be improved. First of all, some have pointed out that the current forms for both the annual financial declaration of parties and the post-electoral declarations of ECs are too simplistic to be capable of capturing all the different types of party income and/or expenditures ${ }^{36}$. This clearly allows for certain 'accountancy engineering' (e.g. parties decide to divide their expenditures, or not, according to their own interests), even if in theory parties are obliged to present their accounts and financial declarations according to their usual accounting rules.

Notwithstanding what has been said, most of my interviewees believe that the solution is not so much an increase of regulation or formal detail, but the introduction of an obligation, or even a best practice, for parties to publish their financial accounts on the internet, with every amount

36 Interestingly, an exemplary document of parties' financial declaration is issued by the (partisan) Minister of Finance, in charge of paying the subvention, rather than by the PKW. 
of income and expenditure registered in detail. In this way citizens would be able to judge who received what and from whom, and on what parties and electoral committees spent their money. The problem with this 'transparent' solution is that not everything that appears in the parties' accounts equals the truth.

Secondly, it is difficult to judge to what extent certain expenditures are connected with the statutory activities of a party, or whether the purchase of certain expertise reports are really worthy the amount paid for them. The only way to be perfectly congruent with the constitutional principle of transparency would be to have the report made available for public scrutiny. However, is it legitimate to ask a party to publish a report about 'its strategy to win the... elections'? This clearly points to the idea that transparency also has its limits.

There seems to be a general agreement among Polish politicians, academics, experts, etc. that the burden should be on the parties themselves, rather than on the PKW as it is right now. The main idea is that the PKW should take care of financial control only, rather than of financial transparency as well.

Although related to ECs rather than parties, one clear improvement in the current legislation is the obligation of the former to have their own website, where they are obliged to record sources of income as well as payments which are higher than the minimum country salary. Thus, every EC has to inform the PKW, after registration, about their website address so the PKW can publish a list with all ECs' websites before the electoral campaign starts. The idea behind this is that voters can take a look at how ECs are being financed and how well they manage their budget, and later vote consistently with their own assessments. The PKW maintains a daily control during the campaign of the information published in such websites. So if something seems to be inaccurate, the PKW can get in touch with the specific EC and ask for corrections/clarifications. Moreover, ECs are obliged to include electronic attachments to the information published in their websites in their post-electoral declarations. It is only when the PKW finally 
publishes such information that the maintenance of such websites is no longer required.

One of the main problems is that, although theoretically extended to all ECs, parties are in practice exempt from this obligation as their ECs are not directly funded by people, but only through a special electoral fund (see above). Unfortunately, and even though there have been suggestions calling for the extension of such an obligation to parties, currently the PKW's answer to queries regarding the funding of this or the other party during elections is the following: please come back again in September (i.e. after the annual financial declaration of parties are examined). The problem is that by then the elections have already passed and the voters' interest is clearly lower, if not non-existent.

Moreover, it could well be that ECs present falsehoods in the information published in their websites. This will be clear only after the PKW has examined their electoral declarations (after elections). The problem is that currently the publication of such inaccurate information is not punishable (at least not in monetary terms ). However, this would not be very difficult as under the Ministry of Finance's orders each EC has the obligation to guarantee the identification of when and who introduced changes in the website (as is the case for every public information bulletin in the country, including the PKW's own website).

In terms of the evaluation of the current system of financial control of parties, and notwithstanding the above-mentioned problems, most interviewees (mainly party members and journalists) consider that, although it could be improved (PO sees it as extremely bureaucratic), the current system is sufficient and appropriate. For the SLD the current system of control could be improved, even by increasing the competences of the PKW, but it is not something extremely urgent, or even necessary. The problem may be, however, that institutionalizing certain forms of social control (e.g. controlling the number of billboards, leaflets, etc.) would not only increase the costs of control (the PKW would need to hire more personnel, spend more on materials like photographic cameras, cars, etc.), but also increase the prices for certain services, as 
certain providers (e.g. experts, printing houses, etc.) may be reluctant to be the subject of such stricter control.

As with most of my interviewees, both SLD and PSL consider that the most important control should take place at the level of society. The idea is not so much about increasing control per se, but rather promoting transparency, especially in terms of how public subsidies are spent (PSL is working on a proposal in this regard). If, as a PSL former minister has put it 'democracy is about citizens getting involved in politics, media exerting control over parties, and voters punishing or rewarding those parties', then the best solution would be a social, rather than institutional, control. In order to achieve that, any increase in the financial (but not only) transparency of parties (e.g. publication of party bills, precise financial declarations, etc.) would be an improvement. As Józef Stefańczyk reminded me, there is already a precedent in the 2010 presidential elections, where all ECs were obliged to publish their bank loans, the conditions under which they were taken, the identity of significant donors, etc. He went so far as to propose 'an obligation for every party to publish, every four months, from where their money is obtained and on what it is spent'. In this same context, one shouldn't underestimate the importance of individual denunciations. However, when the low number of denunciations or the passivity of Polish society was pointed out, most interviewees thought this was just due to the fact that Poland was a very new democracy and that time was still needed for the political education of Poles.

Even for others (TR), social control should be always complemented with the (voluntary) internal control of parties themselves. So the solution is not so much about increasing the regulation or introducing new obligations, but to encourage parties to adopt internal rules/practices in order to increase their financial transparency (but not only). In Krzysztof Iszkowski's (TR) opinion, it would be enough for one party to start publishing their contracts and bills on the internet, and the others would follow suit. Moreover, this would definitely lead to an end of the 'most stupid expenditures' (e.g. hairdressers, suits, etc.). However, even if such 'internal' obligations/practices began to become mandatory rather than 
voluntary, parties would still always find ways to go around the law. One current example of 'torturing' the law refers to a case whereby a public company which, because of its popularity, did not really need to resort to any type of advertising, decided to hire billboards throughout the country for a rather high price. Then the party of the Minister in charge of the public company hired the same advertising spots for the party's billboards, obtaining an enormous discount (on account of the premium price previously paid). Another example took place at the time Janusz Palikot split from PO and founded TR. Because individual donations are limited, he presumably gave his own money to different people (mostly students, unemployed, and retired, but not only) so they could make donations (within the individual limit) to his own party ${ }^{37}$. The same thing can happen if the owner of premises, wishing to support his/her party, simply rents the premises for 1 PLN plus VAT, trying in this fashion to go around the legal prohibition of rendering voluntary work (except for the distribution of leaflets or hanging of banners/posters/placards). As the PKW's control is not directed by market prices, even a company could finance a party in this way.

However, as Krzysztof Iszkowski has put it this does not mean that voters would necessarily start to abandon parties carrying out unpopular practices, but at least it would increase transparency as well as the possibility to report suspicious activities/operations, thus allowing citizens to make a more reasoned choice. Indeed, with such measures voters would not be able to complain that they cast their vote ignoring the fact party $\mathrm{X}$ was doing this, or that party $\mathrm{Y}$ was doing that.

In the opinion of Dominika Wielowieyska, a long-time journalist working on party finances in Poland, the role played by the Polish media in this context has increased (and improved) over time. Still, it is essential to increase party transparency: it would be enough if parties

37 As another example, parties can organize meetings in restaurants which, banned from selling alcohol, simply add beer or wine to the menu (for free), while offering a more expensive menu (i.e. the alcohol is implicitly included in the final price of the menu). As a result, the alcohol does not appear in the final bill. 
published on their websites from whom they obtained money and how they spent it. This would clearly facilitate control, not only by society but by the media as well. The PKW not only does not have the means to go beyond a formal control, but also could be accused of favouring this or that party. It is society itself that has to take over this role. Indeed, the contemporary electronic means available make a nearly daily control possible, allowing voters not only to give or withdraw their support, but also to report (either to the media, the PKW, or the police) any illegal activities a party may undertake. Still, experts and academics (e.g. Adam Sawicki and Jarosław Zbieranek) are very sceptical about such social control in Poland, where not only has society demonstrated a total apathy toward this issue, but also political parties tend not to present complaints against each other, afraid that similar practices will be discovered in their own operations.

At the same time, one of the spheres that tends to escape the PKW's control is the funding and expenditure of electoral candidates. It should be noted here that Poland employs a proportional system of open electoral lists. This, in some places, has led to an electoral battles within parties themselves (i.e. for higher positions on the list), rather than among the parties. This is not to say that candidates in the lower positions on the list cannot make it into parliament. But money plays a critical role in the chances of obtaining a mandate.

In general, but especially in parties with limited budgets, parties distribute money and impose limitations on party expenditures depending on the position a candidate occupies on the list. Obviously, candidates in the upper ranks of the list are allocated more money and allowed to spend higher amounts. Still, candidates can increase their intra-party expenditure limits by asking those in the lower ranks of the list, and thus with lower chances of being elected, to relinquish their limits in exchange for support in local elections, future jobs, etc. However, in many cases these candidates do not want to give up their dreams of becoming elected and will do everything, even spending more money than they are allowed, to fulfil these dreams. The problem is that this can become problematic for the party, as it will 
certainly increase its expenditures as a whole, putting the party in peril of crossing the national expenditure limit, which would definitely lead to the imposition of sanctions by the PKW. Obviously the party can ask the candidate to stop the expenditures, but if the candidate doesn't want to comply there is not much that the party can do except for reporting such behaviour to the $\mathrm{PKW}^{38}$. The problem is that because the party, rather than the individual, will be sanctioned, parties tend not to report such practices in the hope that they will not be discovered. Because this is a common practice within parties, opposing parties tend not to report on each other either, conscious of the fact that some of their candidates may be doing the same thing. And as we have already shown, if not reported this kind of behaviour tends to go undetected by the PKW's strictly formal control. This is especially the case if we take into consideration the large number of candidates fighting for the same places. However, and despite PO's programmatic proposals for adopting the FPTP (first past the post), the possibilities for a change of the electoral system are minimal. It is not only that current MPs do not want to change the system that got them elected (especially those who started from low places on the electoral list). It is also that a German-style electoral system is closely identified with the one employed during communism, and closed lists are seen in Poland as being anti-democratic.

\section{Sanctions}

In clear contrast to the $1990 \mathrm{PL}$, which as we have seen left almost all illegal financial activities unpunished, the current 1997 PL (as well as the $2001 \mathrm{KW}$ ) establishes two different types of sanctions: administrative and criminal. The former include the reduction of the subsidy, the loss of the right to subventions, and the removal of the party from the Party Register when (1) a party does not submit the annual financial

38 Asked about the possibility of establishing internal norms in this regard, our experts pointed to the fact that if a candidate crosses the expenditure limit but gets elected, the party will definitely not punish him/her. 
declaration within the time limit, (2) such (submitted) declaration is rejected by the PKW, or (3) the Supreme Court decides to reject a party's complaint. The criminal sanctions include fines up to 100 thousand PLN or the imprisonment of responsible persons for up to two years, both of which are to be considered the most relevant.

Interestingly enough, since 2001 (when the current system of sanctions was consolidated), no final and valid convictions have taken place although some minor parties have been deleted from the Party Register due to their failure to present their annual financial declaration on time. Still, the only relevant sanction during the last twelve years has been the loss of the right to receive the annual subvention, imposed on PSL after the PKW rejected its 2001 annual financial declaration. Basically, what happened was that PSL accountants forgot to read the new regulation and, therefore, continued to directly finance their (2001) electoral campaign rather than go through the (mandatory) electoral fund. As a result, the party not only lost the dotation and had to give back the money 'illegally' spent, but also lost the annual subvention for three years. Not happy with the sanction, the PSL appealed the decision in the courts, although the final resolution was recently confirmed by the Supreme Court. The problem is that the sanction contained a significant sum of accrued interest, increasing the amount of the sanction exponentially ${ }^{39}$. This has put the PSL party up against the ropes, making it very difficult for the daily financing of its activities.

One of the problems, however, with the current framework of sanctions is that the processes to apply the penalties provided for in both the KW and the PL take extremely long. As Adam Sawicki has pointed out, even if the sanctions included an administrative fee of 1 million PLN or life imprisonment... they would still need to be applied! Instead, there have been cases of candidates spending more money than was permitted, even with the (implicit) consent of their own party, and because the process

39 In 2013, PSL agreed with the Ministry of Finance to a five year extension (PSL asked for ten) of the period in which the sanction (plus the accumulated interest) needed to be paid. 
to punish such behaviour took so long it had no influence on either the electoral results nor in the reception of subventions by the party. Moreover, the elected offenders were able to end their mandates as MPs. The same is true in those cases when a candidate falsifies the minimum number of signatures to run in the elections ${ }^{40}$. Usually the process takes so long that by the time such candidates are officially condemned, the legislative period has already finished.

However, even though most academics and experts, reflecting the social view, think that the process is insufficient, it is interesting to note that the parties (e.g. PO, SLD) tend to consider the current framework of sanctions as very strict. Thus, in the opinion of SLD's Secretary 'sanctions are very high, as even a formal mistake can lead to the loss of the subvention until the end of the legislative period'. Alternatively, SLD would be in favour of imposing a proportional (or double at most) sanction to the illegal action committed. For others (e.g. $\mathrm{PiS}$ ) sanctions need to be increased in order to avoid situations where spending in excess can lead to financial gains or, if declared, simply to an administrative fine, rather than the loss of the annual subsidy (as is the case if a party does not declare it). For others (e.g. PSL, journalists) there is no need to change the present regulation as the possibility of losing the annual subvention is the worst penalty a party may face.

However, as pointed by the two journalists I interviewed, the two most important problems in this respect are the following: on one hand, not only parties as organizations tend to escape the application of penalties, but also individuals who, being responsible, were fortunate enough not to get involved in a written form ${ }^{41}$. On the other hand, sanctions are almost never applied (e.g. Palikot's case). This is due not only to the fact that the PKW's control is strictly formal, but mainly to the difficulties faced by the Public Prosecutor to prove certain illegal

40 Although the procedure has been simplified, it used to be the case that the court was obliged to hear every single person (often more than 3000) connected with the infraction.

41 As pointed out by our experts, parties or candidates have rarely been punished for crossing their allocated expenditure limits. 
deeds, as well as a reluctance or fear on the part of the Courts to get involved in politics. In Poland, both judges and prosecutors are afraid of being accused of partiality. Indeed, most interviewees confirmed that the prosecution of a party before elections would be considered as an interference into the fairness of the results. In a similar vein, the prosecution of an opposition party after elections would be seen as a kind of punishment by the ruling party in government. And the prosecution of the ruling party in government is simply considered to be risky. Thus, the general view of Polish society, confirmed by every single interviewee, is the following: the 'rules' are viewed as general reminders, brakes that need to be there so things do not get out of hand. In fact, people tend to think that illegal behaviour on the part of political parties is part of the political game. Thus, those who are caught breaking the rules can always claim that it would be impossible otherwise, and that the opposing parties are doing even worse. However, the important thing to remember here is that if a certain wrongdoing is not egregious and does not influence the final electoral results, then it is considered not worthy of prosecution.

\section{Conclusions and suggestions for further improvement}

All in all, and in clear contrast to the majority of Polish citizens (at least those who voted in the referendum), most Polish politicians are in favour of maintaining the current status quo, perhaps with very minor improvements. The idea is that although the current regulatory system is not perfect, by putting an end to most illegal sources of funding and increasing the control over both parties' and individual politicians' finances, it has managed to exponentially decrease the party corruption rampant in the 1990s to levels rather acceptable at the beginning of the third decade after the re-inauguration of democracy in 1989. As most have recognized, party corruption and/or inappropriate enrichment by politicians certainly continues to exist (as Batory Foundation electoral observations have clearly discovered), but on a much lower scale than previously. In the opinion of most observers, corrupt structural practices 
and so-called 'primitive corruption' (i.e. personal gains, abuse of public money, etc.) have been almost eradicated. As a result, the democratic system is not considered to be in danger.

Notwithstanding this rather generally positive evaluation of the current regulatory framework, on the basis of what has already been discussed I would like to propose some regulations and items that could perhaps increase its effectiveness:

1. Specific regulations regarding unacceptable party expenditures paid with public money (e.g. suits, hairdressers, alcohol, cigars, etc.);

2. More detailed and specific forms, designed by the PKW itself rather than the Ministry of Finance, to be used in the parties' annual financial declarations;

3. In relation to the above, there should be an obligation on the part of parties to declare 'who, why and how much' has been received or spent;

4. There should be public access not only to bank statements or electoral campaign bills, but also to every single receipt linked to parties' ordinary purchases;

5. The documents mentioned in the previous point should be published online by the parties themselves, at least on a yearly basis (or every six months if possible);

6. Longer control periods or conditional ${ }^{42}$ subsidy payments should be established by the PKW;

7. A public (phone or e-mail) 'hot line' should be established so the PKW can receive anonymous reports regarding parties' illegal activities (either in breach of the KW or the PL);

8. Greater attention should be given to the control of individual candidates' expenditures at the time of elections;

9. A stable and highly professional unit of independent financial auditors should be created within the PKW's organization chart;

42 This will eliminate the current temporal mismatch between the PKW's control periods and those of other state audit institutions (e.g. Tax Office). 
10. There should be financial control of foundations and/or associations, either by the PKW or another competent organ (e.g. supreme audit office);

11. There should be stricter sanctions for 'formal' mistakes in parties' annual financial declarations. This will not only encourage the professionalization of party accountants, but also avoid situations where non-subsidized parties (e.g. SD) present inaccurate financial declarations (the only aim being to avoid dissolution).

\section{References}

Biezen, I. van, Mair, P. and Poguntke, T. (2012). Going, Going... Gone? The Decline of Party Membership in Contemporary Europe. European Journal of Political Research, v. 51, n. 1, pp. 24-56.

Casal Bértoa, F. and Biezen, I. van (2017). The Regulation of Post-communist Party Politics. Abingdon/New York: Routledge.

Casal Bértoa, F. and Spirova, M. (2013). Get a Subsidy or Perish! Party Funding and Party Survival in Europe. The Legal Regulation of Political Parties Working Paper Series (n. 29).

Casal Bértoa, F. and Walecki, M. (2014). Regulating Polish Politics: 'Cartel' Parties in a Non-Collusive Party System. East European Politics, v. 30, n. 3, pp. 330-350.

Hartliński, M. (2015). The 2015 Referendum in Poland. East European Quarterly, v. 23, n. 2-3, pp. 235-242.

Walecki, M. (2005). Money and Politics in Poland. Warsaw: ISP.

\section{Main legal texts examined}

Constitution of the Republic of Poland of 2nd April 1997. Available at: http:// www.sejm.gov.pl/prawo/konst/angielski/kon1.htm [Accessed: Jan. 2015].

Act of 27th June 1997 on Political Parties. Available at: http://www.sejm.gov.pl/ prawo/partiepol/partiepol.htm [Accessed: Aug. 2014].

\section{Interviewees}

1. Krzysztof Lorentz, Director of the Financial Auditing Unit of the PKW.

2. Maks Kraczkowski, PiS MP. 
3. Dominika Wielowieyska, Gazeta Wyborcza.

4. Marek Sawicki, PSL MP and former Minister of Agriculture.

5. Marcin Święcicki, PO MP.

6. Maciej Klima, SP MP.

7. Kazimierz Ujazdowski, PiS MP and former Minister of Culture.

8. Krzysztof Gawkowski, Secretary-General of SLD.

9. Krzysztof Iszkowski, Director of 'Plan for Change' (Plan Zmian), TR's think-tank.

10. Adam Sawicki, specialist for the prevention of corruption and project coordinator at the Institute for Public Affairs (Instytut Spraw Publicznych). Former employee of the FB.

11. Józef Stefańczyk, former PSL MP.

12. Jarosław Zbieranek, Head of the Law and Democratic Institutions Programme at the Institute for Public Affairs (Instytut Spraw Publicznych).

13. Karolina Tomaszewicz, TV Republika.

Fernando Casal Bértoa is an Assistant Professor in the School of Politics and International Relations at the University of Nottingham (United Kingdom). His work on party regulation and party system institutionalization has been published, among other in European Journal of Political Research, Sociological Methods and Research, West European Politics, Party Politics, Democratization, European Constitutional Law Review, Political Studies Review, Government and Opposition and East European Politics. He was awarded the 2017 AECPA Prize for the Best Article.

\section{Fernando Casal Bértoa}

University of Nottingham

School of Politics and International Relations

Park Nottingham NG7 2RD, United Kingdom

e-mail: Fernando.Casal.Bertoa@nottingham.ac.uk 